\title{
THE GABION HOUSE REVISITED
}

\author{
Regan Potangaroa
}

Department of Architecture, UNITEC, New Zealand

e-mail: potangaroa.regan54@gmail.com

\begin{abstract}
Most material on a "Green Concept" for addressing the environmental, social, cultural and institutional issues resulting from global warming and climate change through the implementation of architecture and environmental design usually starts with the "big" picture, policy/theoretical statement. And then migrates towards the "specific design" criteria. However, there is a problem with this approach and experience questions whether it adequately or often appropriately connects with practice as it migrates?The paper revisits a community in Port au Prince Haiti that received gabion houses constructed as part of the response to the 12 January 2010 earthquake. The gabion house was perceived within the humanitarian shelter community as an excellent green concept because it reused rubble, could be built using local skills and was economical comparable to other options. Thus, the question posed to the community after nearly 2 years of living in these gabion houses was whether the houses were more effective than the "standard" house? And from that reflective process are taken design tips for possibly a more humane and Greener Concept.
\end{abstract}

Keywords: disaster, design, reflective

\section{ABSTRAK}

Sebagian besar material pada "Konsep Hijau” (Green Concept) untuk mengatasi isu lingkungan, sosial, budaya, dan institusional yang dihasilkan dari pemanasan global dan perubahan iklim melalui penerapan perancangan arsitektur dan lingkungan biasanya dimulai dengan gambar "besar", pernyataan kebijakan/teoritis. Dan kemudian berpindah menuju kriteria "rancangan spesifik". Namun, ada masalah dengan pendekatan ini dan muncul pertanyaan apakah itu memadai atau seringnya tepat terhubung dengan praktek sebagaimana itu berpindah? Makalah ini mengunjungi kembali sebuah komunitas di Port Au Prince Haiti yang menerima rumah gabion yang dibangun sebagai bagian dari respon terhadap gempa 12 Januari 2010. Rumah gabion dianggap oleh komunitas shelter kemanusiaan sebagai konsep hijau yang sangat baik karena menggunakan kembali puing-puing, dapat dibangun menggunakan keterampilan lokal dan ekonomis dibandingkan dengan pilihan lain. Sehingga, pertanyaan yang diajukan kepada masyarakat setelah ham- 
pir 2 tahun tinggal di rumah-rumah gabion ini adalah apakah rumah-rumah ini lebih efektif daripada rumah "standar"? Dan dari proses reflektif itu diambil tips desain untuk mungkin sebuah konsep yang lebih manusiawi dan lebih hijau.

Kata kunci: bencana, rancangan, reflektif

\section{INTRODUCTION}

A green design concept often starts from the objectives of the original Green Concept and consequently is invariably set in a "policy" rather than a "design" format. For example, what does it mean to be "safer", "healthier", "more liveable", "more equitable", "sustainable" and "productive" under the Habitat II Agenda item 1? (UNHABITAT, 1996). Practitioners invariably "guess" what that means for design but in the humanitarian field (where this case study is situated) issues are defined explicitly by the UNHCR Handbook (UNHCR, 2007) for refugee situations and the SPHERE Handbook (SPHERE, 2011) for internally displaced ones. And despite not having to "guess" the issues still remain such as does a minimum of $3.5 \mathrm{~m}^{2} /$ person for the area of shelter with a minimum height of 2 metres at one point really represent the "dignity" and the "durable solution" sought by humanitarian agencies?

A Richter scale 7 earthquake struck Haiti on January 12, 2010 at around 5pm. It was shallow and located 22 kilometres from the capital city of Port au Prince and resulted in 230,000 fatalities and extensive building damage in the city. Such figures were unfortunately not surprising given that Haiti did not have any seismic code and in the year before there was the collapse of 3 schools due solely to gravity loads with the largest in Petionville causing 92 deaths (Reliefweb, 2008). Building standards are minimal, and enforcement essentially nonexistent in Haiti.

A UN Habitat study (UNHABITAT, 2009) of the informal settlements in Port au Prince in 2009 (one year before the earthquake) indicated that over $50 \%$ of its 2.7 million metropolitan inhabitants lived in "informal" settlements with minimal if any legal land title. Such areas are characterised by limited or no access to safe drinking water, sanitation and waste collection with 53\% living in ravines (steep gullies prone to flooding at the bottom) and $38 \%$ on steep hill sides prone to landslides. They are connected by a maze of steps, pathways, alley ways and narrow lanes. Roads are under sized throughout the capital city and hence traffic grid lock is the norm. Despite all this, the houses are built of "solid" concrete materials with concrete floors, reinforced concrete frames and concrete block infill walls. Haiti was identified in the study as the poorest country in the western hemisphere with $76 \%$ earning under the \$2US/day poverty line with the average income for a poor family being \$0.44US/ day. Despite that (or perhaps as a consequence) Haiti is one of the most densely populated countries in Latin America with 310 inhabitants per square kilometre.

Thus, it was not surprising that the 2010 earthquake also resulted in over 1.3 million people having to live in temporary camps and as the response drew out past one year and on to its second, pressure mounted on the humanitarian community to find more durable solutions than tents. 


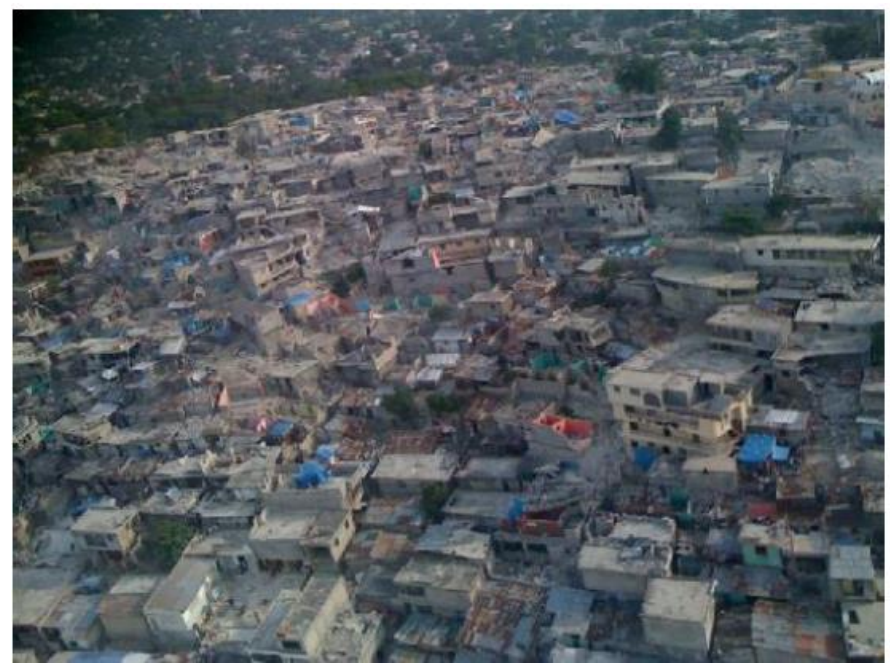

Figure 1. A Typical Haitian Informal Housing Context. Source: field survey, 2011

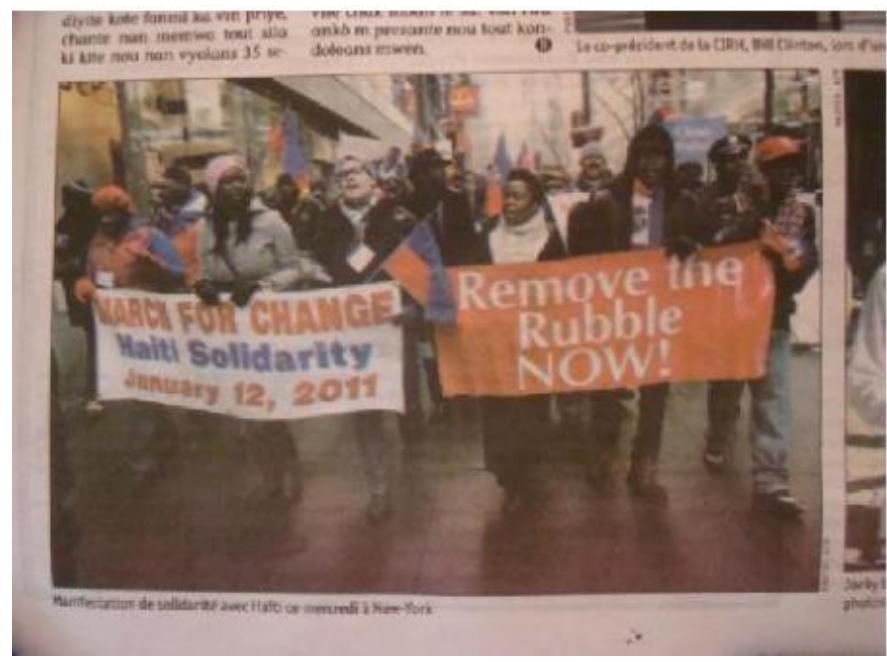

Figure 2. Rubble was A Political Issue One Year after The Earthquake.

Source: March for Change Protest New York 12 January 2011

One major obstacle was the rubble generated by the extensive building collapses in the ravines and hill sides that blocked the maze of alleyways and lanes. Early estimates put it at around 20 million cubic metres with later more accurate measurements placing it at around 10-11 million (BBC, 2011). But even that lower figure represented 27.4 years of local production with all 3 quarries working 24/7. Moreover, the cost of mechanically clearing and dumping the rubble was estimated at between US\$32.50-\$58 per cubic yard (New York Times, 2010) by one source and US\$26-\$80/tonne by a second source (SKAT,2000) with a cost of between 
US\$20-25/tonne (based on local costs to a "typical" site) to bring in new material. Hence, it was going to cost in the order of US\$500 million and take 27+ years just to get ready to reconstruct the houses lost in the earthquake.

Hence, the idea of re-using the rubble in the form of gabion blocks to rebuild rather than extract, remove and dump it. This was also combined with the option of hand and mechanical crushers to further re-process the rubble into aggregates for concrete, alleyway base course and plastering sand (CHF, 2011).

\section{What is A Gabion House?}

A gabion is a wire cage (Geiger, 2012) into which are placed rocks that are stacked vertically to form retaining walls. In this case they were designed for housing (Temporality 109, 2012), (Mulligan, 2012), (Enviromesh, 2008). The cages were lined with chicken mesh and the rock material selectively placed and compacted into the cage and topped with smaller aggregate material (see Figure 3 ). The cage sizes were typically $600 \mathrm{~mm}$ long by $300 \mathrm{~mm}$ high and $300 \mathrm{~mm}$ wide. They were laid in a stretcher bond, wired together both vertically and horizontally with the gabion tops open to enhance interlock between layers (Brennan, 2011).
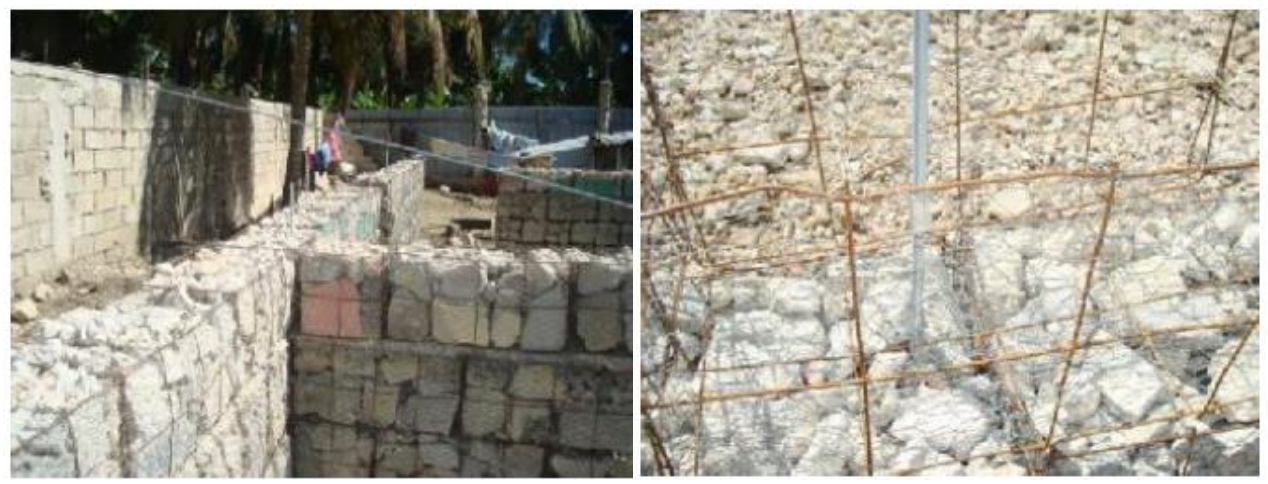

Figure 3. Gabion House 1 Walls Under Construction. Source: field survey, 2011

Seismically, they were reinforced vertically with $12 \mathrm{~mm}$ threaded rods at approximately 2 metre centres that were anchored into the gabion foundations and clamped at the top of the wall to a $150 \mathrm{~mm}$ deep concrete bond beam. Plan dimensions were kept under 3:1 (length to width) and 1:1 for walls (height to length). A low ductility of 2.5 was used for an earthquake with a $10 \%$ exceedance in 50 years (Brennan et al, 2011). 


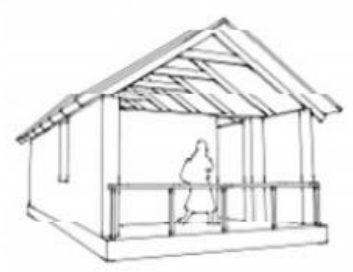

SIDE VIEW VERANDAH

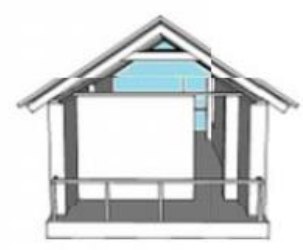

FRONT VIEW VERANAH

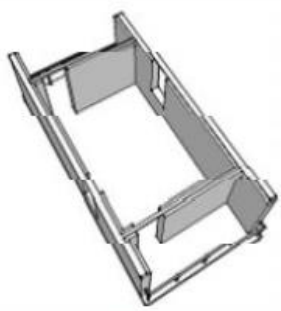

TOP VIEW

Figure 4. The Gabion House Green Concept

The overall cost of constructing a 9x4.8 metre gabion house (as shown in Figure 4 above) in December 2010 was US\$3964.50 (US\$92/m²) (see Table 1). This would be less depending on labour costs, proximity of rubble, and size and amenities included in the house. Typical costs for other new houses were in the US\$170$200 / \mathrm{m}^{2}$ and therefore the gabion concept was an economic housing option.

Table 1. The Gabion House Costs

\begin{tabular}{lr}
\hline \multicolumn{1}{c}{ Item } & Projected Cost \\
\hline GABIONS & \\
5 Rolls of square mesh & $\$ 900.00$ \\
6 Rolls of chicken wire & $\$ 500.00$ \\
CEMENT & \\
35 bags @ \$7.50 & $\$ 262.50$ \\
JOINERY & $\$ 102.00$ \\
3 sheets of 18mm ply @34 ea & $\$ 250.00$ \\
Doors and windows & \\
RUBBLE & $\$ 200.00$ \\
Cost of collection \& transport & \\
LABOUR & $\$ 130.00$ \\
Making of gabions & $\$ 130.00$ \\
Filling gabions & $\$ 480.00$ \\
Crushing rubble & $\$ 160.00$ \\
THREADED ROD & $\$ 250.00$ \\
PLASTERING & $\$ 600.00$ \\
ROOF & $\$ 3,964.00$ \\
TOTAL &
\end{tabular}

\section{THEORY / RESEARCH METHODS}

The opportunity was taken to revisit and interview the 4 families in Lilavois (a suburb of Port au Prince) who were supplied with a gabion house as part of the earthquake response to see whether the perceived advantages of a gabion house over more standard housing solutions had succeed or not? The interviews were done in 
February 2012 but only 3 of the 4 were eventually available. All 4 were neighbours with households 1 and 2 being part of an extended family (or "Lakou" in Haitian) and houses 2 and 3 being redesigned from the original concept shown in figure 4 to one where they shared a common boundary wall. This was done for spatial and social equity issues that allowed better use of the surrounding space and also so that house 3 did not extend pass its original foundations and thereby become larger than his brother's house that was on the same site (see Figure 5).

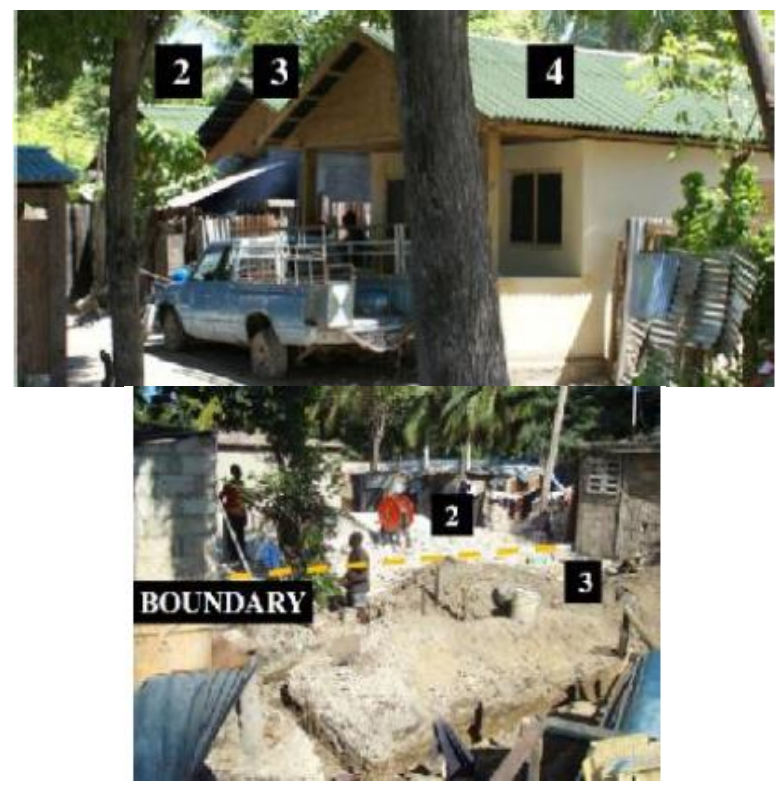

Figure 5. The Gabion Houses 2 to 4 and The Boundary Issue between 2 and 3 . Source: field survey, 2011

A short narrative survey based on observations and expected outcomes for families from the gabion house concept team and from a literature review was compiled and this is in appendix A. The interviews were completed by local Haitian shelter field staff who worked for a large aid organisation that was not the original International Non Government Organisation INGO constructor of the gabion houses. Prompts and some background details and intents of the survey questions were added but it was emphasized that it was their narrative rather than a response to each question that was being sought. The interviews were digitally taped and responses analysed using the categorisation from the Kestle Value Adding Framework (as defined by the "customer") that are as follows (Kestle, 2009):

1. Timely Decision Making: the characteristic of summing up a situation/s and making a decision in a time frame relevant to it. This can be with less than full information and hence there can be a trade off between being 'timely' on one hand while on the other being 'impulsive and impatient'.

2. Process Integration: is essentially a holistic approach that underlines the unity of the overall process rather than the optimization of any part of it. 
3. Knowledge Integration: is the process of threading, merging or possibly synthesizing of knowledge from various viewpoints into a larger more expansive model or framework.

4. Value Generation: refers to the value that the client and stakeholders place on the project outcomes, and will vary according to the differing clients' and stakeholders' expectations of the project/s, and these can vary not only between stakeholders but also between client groups.

\section{RESULTS AND DISCUSSION}

Comments from the full interviews were noted in each of the framework characteristics and matches and mismatches identified. In the "match up area" it seemed that the major value adding component was via value integration. The perception amongst all of the households was that the gabion house felt safer, offered better protection and security and was stronger than other existing houses or new houses provided as part of the earthquake response they had visited. This largely seemed because of the extent and thickness of the gabion units at around $400+\mathrm{mm}$ thick once they were plastered from their original $300 \mathrm{~mm}$. This can be felt in the photographs in Figure 6 below. This had not been expected by the original Green Concept team (which the author had been a member) but it was nonetheless, pleasantly surprising. Interestingly, the thickness created "unintentional" transitional spaces at doors and window reveals.
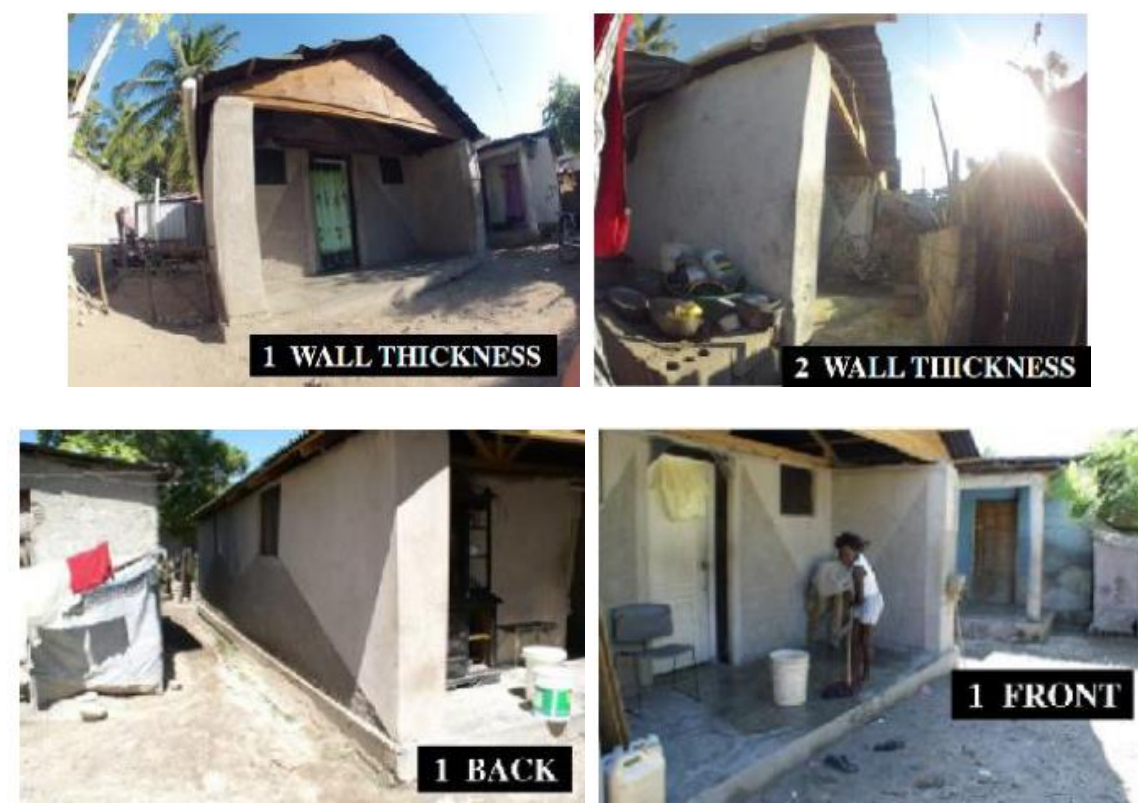

Figure 6. A Sense of The Gabion House's Comparative Dimensional Size to The Usual Houses.

Source: field survey, 2011 
The other aspects of the Value Adding Framework of knowledge and pro-cess integration and timely decision making were minor though the process integra-tion and timely decision making related to house additions was apparently prevented for the first 3 years. Despite that house occupants had installed "kitchens" which can be seen in the photographs of Figure 6 (refer to "1 Back": kitchen can be seen in the back of the house; "2Wall Thickness": kitchen on the side of the house). What is interesting about both is that the wall thickness allows hot kitchens to be placed directly against them. This can be done against concrete block for example but would quickly lead to degrading of the low quality blocks commonly used and perhaps a more slower one for quality one.
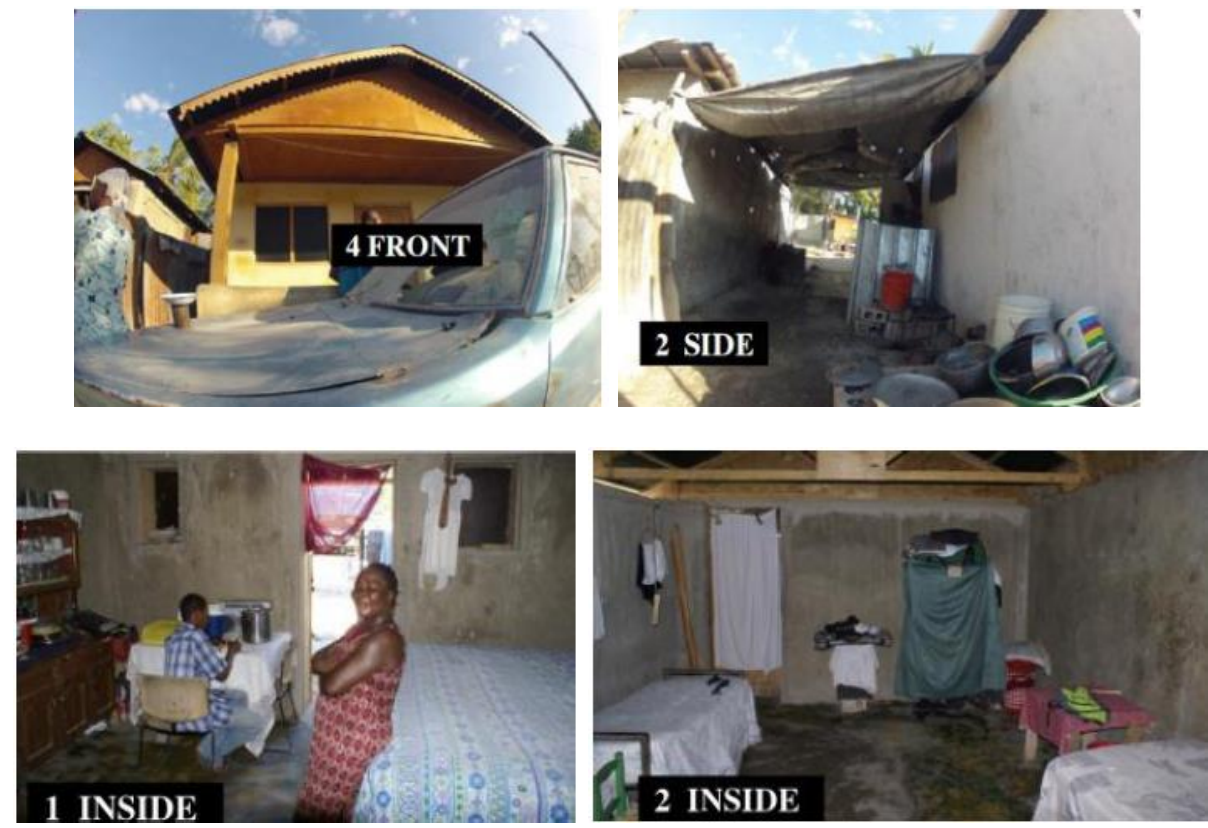

Figure 7. In and Around The Gabion Houses.

Source: field, 2011

All identified issues with the roofing and several with natural ventilation and cooling. The temperature lag due to the mass and thickness of the walls could be expected to result in a cooler house. Where there was a cross ventilation situation this seems to have been realised but not in 2 and 3 that has a common boundary wall. Both of these issues could be perhaps better dealt with by having a roof slope greater than $20^{\circ}$. This would generate better cross ventilation at the ceiling level inside the house and would also reduce rainwater leakage as the roof covering aged. It would also seem that mass alone may not be able to compensate for reduced ventilation in terms of thermal lag. Certainly more quantitative work could be done in this area. In and around of the gabion house can be seen in Figure 7. 


\section{Discussion}

The house owners felt safer and certainly the seismic design was to a high level being both conservative and being based on low ductility and internationally accepted seismic standards. Moreover, it had several other advantages such as cost, low skill levels making training readily transferable, recycled and reused what would have been otherwise a waste material and allowed direct contracting and expenditure within the affected community. However, the main conclusion from these interviews in terms of design was that "big was beautiful" and certainly something akin to human scale seemed to be about "right". (Alexander et al, 1977). Thus, the design problem initially formulated and outlined earlier did not seeming matter to those occupying the house. They wanted/needed to feel safe and some solid and larger appeared to suit that need. They made use of the particular spatial layout which could have been the case with other house types. The expected thermal lag advantage of the house's mass was perhaps disappointing but may have been because two of the houses had a common boundary wall; which is supported by Zhou (Zhou et al, 2008). Thus, a gabion house may not be advantageous with row housing and is perhaps best suited for individual ones. That would need further quantitative work.

One of the difficulties of researching the design interface (as has been attempted thus far) is that it does not necessarily follow scientific distributions and is not dependant on achieving sample sizes to find potential solutions to problems. These are the so called patterns and as noted by Alexander and his team "At the core... is the idea that people should design for themselves their own houses, streets and communities. This idea... comes simply from the observation that most of the wonderful places of the world were not made by architects but by the people". And that there was in this case a difference between what was seen as a Green Concept and how that was interpreted by those occupying the houses.

On the other hand, the reflective approach above can be biased and possibly shallow in its application. Thus there is a need for some level of triangulation in the analysis which in this case is back stopped by the household surveys, the Kestle framework and existing literature. I suspect that this tension will never fully be resolved and that there will exist a sense of ambiguity when policy and practice meet (Kates et al, 2005).

Collier has an interesting perspective and suggests that for the poor one would find the other aspects of Kestle's framework collapsing into value generation as we found with this small study. He suggests that from there would form 3 social capital mechanisms (Collier, 1998); "Different parts of the literature on social capital focus on different economic benefits. I suggest that social capital is economically beneficial because social interaction generates one or other of three externalities. It facilitates the transmission of knowledge about the behaviour of others and this reduces the problem of opportunism. It facilitates the transmission of knowledge about technology and markets and this reduces market failures in information. It reduces the problem of free riding and so facilitates collective action. I distinguish between whether the social interaction is reciprocal or unidirectional; and whether it is organized or informal. For example, knowledge transmission may depend upon information pooling, which occurs through reciprocal interactions such as networks (informal) 
and clubs (organised), or upon copying, which only requires unidirectional interaction." Since that work in 1998 there has been growing empirical evidence that social capital contributes significantly to sustainable development. Sustainability is the intergenerational desire to control your present situation as Collier describes "to leave as many, or more, opportunities as we ourselves have had". His comments are particularly relevant to the interpretation of the interviews but not to the role of the gabion house. Any type of house provided would/should have resulted in a similar collapse into value generation but have been included so as to delineate the impacts of a gabion house compared to any other house.

Sustainability is increasingly been sought in humanitarian response, post disaster reconstruction (Natural Hazards Center, 2005) and development (IFRC et al, 2013). However, the translation to design has been problematic as seen in the small case study above. The convergence between sustainability and disaster management continues (Dovers, 2004) with the impacts of phenomena such as global warming, climate change and rising sea levels being increasingly seen in the number and nature of disasters.

\section{CONCLUSIONS}

The basic question was whether the gabion house added value over and above the other standard houses offered as part of the earthquake response in Haiti? And the answer would be a qualified "yes".

\section{ACKNOWLEDGMENTS}

The author would like to acknowledge the Gabion Concept Team who were Chris Howe as the innovator/designer, Hugh Brennan as the constructor and Rafael Matter-Neri as the designer/urban planner.

\section{APPENDIX A: Gabion House Survey Instrument November 2012}

The comments in italics are for those doing the interview.

1. How is this house better and worse than the house you had before the January 2010 earthquake? (we want to know the advantages and disadvantages of the gabion approach from their experience as a starter question to set the context for the remainder of the interview. Another similar question would be what have been the big changes to your life since moving into this house?).

2. Is your house cooler than other nearby houses you know or visit? (the research data suggests that this should be the case and we are trying to confirm it)

3. Is your house drier in the rain? (we are trying to find out whether larger wall sections shed water better than standard thin wall houses?)

4. What improvement have you made to the house? (In general, people will invest money into areas that they see as priority. This may not be the case depending on 
the household income; nonetheless we would like to know if there has been any renovation/changes/improvements and what they are?)

5. If we were to come back and offer to do one improvement to your house, what would you ask us to do? (similar question to the above and depending on their answer to the early question will determine how their answer/s should/could be interpreted here).

6. What do your kids think of the house?

7. If you were able to say "thank you" to your house, what would it be for? (this question firstly seeks to understand how people feel about their house but also what benefits it provided. It invites them to think of their house as an actual person, and what they would say to that person. Note and draw out any specific benefits of a gabion house over say a more "standard" house.)

8. Are there favourite places for you in the house say in the morning, afternoon or evening? Is this different from your earlier house before the earthquake?

9. What do your neighbours, friends and family feel about a gabion house rather than other house types?

10.Have your feelings about your home changed since January 12 2010? How? (Prompts: security, who are living there, cooling, social standing, the aspect of haven, safety, asset, liability, pride, invest time \& energy, want to leave, stay)

11. What does this immediate neighbourhood/street mean to you? (Prompts: connections, identity, time/history, familiarity, social interactions such as school/church, shops, other natural and built features)

12. Have your feelings about your immediate neighbourhood/street changed since January 12 2010? How?

13. What would you like to change in your neighbourhood?

14. How do you feel about Lilavois as a place now after the earthquake? (Prompts: connections, identity, time/history, familiarity, work, social interactions such as school/church, other natural and built features such as shops, cultural and sporting activities)

15.Have your feelings about Lilavois changed since January 12th? How? (Prompt: strengthened/weakened identity).

16. What changes in the environment have led to changes in how you feel about your home/ immediate neighbourhood/street/Lilavois? (Prompts: rubble, roads access, drainage, disused buildings, blocked pipes)

17. What other influences are you aware of that could be affecting your answer to the above question? (Prompts: media reports, NGO's, UN, Govt Depts, local or central government officials) Note: Explore feelings of powerlessness, vulnerability, alienation, ambivalence).

\section{APPENDIX B: A SELECTION OF INTERVIEW NOTES}

Comments and observations by the survey team are noted in italics.

House 1: A strong church family, that according to them meant they should be prepared to welcome other people even those just passing by. No apparent change or differences with her relationship with others because of the house; [Comment: though it was observed how the front design of the house enhanced this capability 
with chairs being placed in it and that children from the house and others played in this area though this was not dependent on it being a gabion house]. There is a lot of things that need to be changed in the neighbourhood, it is very noisy. However, it seems to be similar to that before earthquake and that the house has not changed the neighbourhood. [Comment: However. it was noted that noise level at least qualitatively were lower in this house than other non gabion ones]. People still kept to themselves as it was before the earthquake. Mosquitoes, dust in the air but they now have a good house. There was some confusion and people said that if you accept a house it would give you other opportunities such as being able to travel to the USA. [Comment: this is the dream of most Haitians] No improvements to date because they understood that they were not allowed to do any changes to the house until after 3 years of occupation. [Comment: all the others owners said a similar thing] Nonetheless, the owner did seem keen to add to it [Comment: it is not exactly clear what that could/would be given the compact site] The roofing material used was not good and had started to lose it's corrugated shape [Comment; and also its strength] and had gone "flat" in the Haitian temperatures [Comment: the roofing used was a bituminous corrugated roofing material marketed as Onida in Haiti].Grateful to the house for providing the shelter and protection (apart from the roof) that their previous house did not. Likes all parts of the house that is not especially affected by morning or afternoon or presumably evening. She spend most of her time in the back gallery (kitchen/laundry area).Everyone in the family likes the house and when they replace the roof their feeling was that it would be 2 nd to none in the neighbourhood. The mother found that when she was in other houses even though they were strong she would still run out; where as in the gabion one she felt safe. [Comment: She did not offer any reasons why she felt "safer"] Others commented that it was a "better" material than timber and that gabions "felt" stronger [Comment: perhaps because of its thickness? This was mentioned by several people] The gabion house seemed more durable. House was more water proof during recent hurricanes and wasn't sinking (like the previous one). The kids like the new house but the roof is the issue, it seems that the roof on the previous house was better. She didn't have any problems with the questions.

House 2: House is better than previous, the mother of the household feels safe even when there are ground movements; Trust's the house whereas the previous house was "broken". This house is not cooler than other houses in the neighbourhood. Not enough windows. [Comment: this house shares a common boundary wall with its neighbour and hence has no windows on one side though it has better useable space on the other side] Cool in the morning and afternoons but hot at mid day. Can't say the house is drier as the roof leaks because of the valley gutter detail between the houses [Comment: This house was combined with the neighbouring one and hence the valley gutter detail because of spatial constraints of existing houses for both houses] When it rains they have to wait till it stops and then mop up the floor. They have not spent any money on the house, [Comment: similar to household 1] and were also told that people would return to check out the house. The kids like the house more space to play. The only way to say thank you to the house by giving it a big "hug". Favourite place is the gallerie (balcony or porch area) and in her own room [Comment: subdivision inside the house using curtains]. Friends and passerby 
frequently asked questions as to who did it and they like the design and its relationship to the site and other buildings. However, some neighbours are critical though her church people like it. There did seem to be issues between the mother and the neighbourhood. [Comment: this household did seem to be distant from the other families on the block of land] Despite this there were apparently no changes in feelings after the earthquake compared to before. There was the comment that the house should not be somewhere that looks good but should be a place that makes me feel "safe". Would like others (such as those in tents) to have the same house so that they could have a safe life. The community has changed; people have to travel a lot further to get work- lack of time so people don't have the same contact now as opposed to before the earthquake. The mother felt that people are affected and there are new diseases for those living tents and hence her perception of houses (as being safer) have changed. No problems with the questions.

House 3: Like the house because it is habitable, earthquake safe and secure. (presumably because of the gabions). The mother said that she would not die in it and was more confident in gabion than in concrete block. Feels that it is cooler in the day time and at night. Also drier than other houses in the area. [Comment: this was from flooding rather than from a leaking roof] She and her kids like it, it is perceived as a "gift" so "what more is there to say"? After the earthquake they lived in a house with a concrete roof, the kids were worried about its fragility and they had lots of questions about everyone's safety and possible injuries. They do not with the gabion house. And even though there is only one room and have to share that one room, they are managing. [Comment: the house complies with the SPHERE Standard for space but it is tight nonetheless hampered by insufficient land space] Haven't spent any money but she will build a kitchen. Don't have anything else to add.

\section{REFERENCES}

Alexander, C., Ishikawa, S. and Silverstein, M. (1977), Pattern Language, Oxford Press. ISBN 0-19-501919-9.

BBC, (2011), Haiti earthquake: One year, <http://www.bbc.co.uk/news/world-latinamerica-12135850>.

Brennan, H, (2010), <http://www.flickr.com/photos/43726461@N02/sets/ 72157626067710158/> (Accessed on September 2013).

Brennan, H., Howe, C., Mattar-Neri, R., and Potangaroa, R. (2011), The Gabion House Approach Conference on Disaster Resilience 2011, Sri Lanka.

CHF (2011), Crush, CHF Haiti Project Report January 2011.

Dovers, S. (2004), Sustainability and Disaster Management, The Australian Journal of Emergency Management, 19(1), March 2004.

Enviromesh (2008), Designing with Gabions Volume 2: A Reference Guide for Architectural Gabion Cladding and Free Standing Walls Office at Bristol BS16 $7 \mathrm{FQ}$.

Geiger (2012), Stone Baskets, <http://www.schotterwerk-hgeiger.de/docs/stonebaskets.pdf $>$. 
IFRC and BRE Global (2013), Quantifying the Sustainability In the Aftermath of Natural Disasters QSAND, Information sheet.

Kestle, L. (2009), The development and validation of a conceptual design management model for international collaborative remote site projects, Unpublished PhD thesis, University of Canterbury, Christchurch, New Zealand.

Natural Hazard Center (2005), Holistic Disaster Recovery Ideas For Building Local Sustainability After a Natural Disaster, Revised December 2005

Robert, W. K., Thomas M. P., and Anthony A. L, (2005), What Is Sustainable Development? Goals, Indicators, Values, And Practice, Environment: Science and Policy for Sustainable Development issue, 47(3), April 2005, 8-21.

New York Times (2010), Weary of Debris, Haiti Finally Sees Some Vanish, Oct 17 th, 2010.

Mulligan, M. (2012), The Dominus Winery: A Case Study of an Alternate Masonry System, <http://www.scribd.com/doc/116544464/Dominus-Winery-Case-Study> (Accessed on Sept 2013-09-22).

Reliefweb (2008), Haiti: After school collapse, President admits State responsibility accessed, <http://reliefweb.int/report/haiti/haiti-after-school-collapsepresident-admits-state-responsibility> (Accessed on September 2013).

SKAT (2010), Private Sector Participation in Municipal Solid waste Management, part iii by Sandra Cointreau-Levine pub by SKAT 2000 pg 5, prices adjusted for inflation.

SPHERE (2011), Sphere Handbook: Humanitarian Charter and Minimum Stadards in Disaster Response, 2011 ISBN 92-9139-097-6

Temporality (2012), Refugee Shelters for Ethopia. Wisniewska M, Kifle B, Feleke A, p.108-113, <http://hebel.arch.ethz.ch/publications/shelter_eth_2011.pdf>

UN Habitat, (1996), Istanbul Declaration on Human Settlements, accessed online at <http://www.unhabitat.org/downloads/docs/407-ISTANBUL_DECLARATION_ON_HUMAN_SETTLEMENTSIstanbul_Declaration.pdf> (Accessed on October 9 2012).

UNHABITAT (2009), Strategic Citywide spatial planning: A situational analysis of metropolitan Port au Prince, Haiti UN Habitat.

UNHCR (2007), Handbook for Emergencies United Nations High Commissioner for Refugees, Geneva Third Edition February, 2007.

Zhou, J. and Zhang, G. (2008), Coupling of thermal mass and natural ventilation in buildings, Energy and Buildings, 40, (2008) 979-98. 